\title{
Salicylic Acid Conjugated Dendrimers Are a Tunable, High Performance CEST MRI NanoPlatform
}

\author{
Wojciech G. Lesniak ${ }^{\dagger}$, Nikita Oskolkov ${ }^{\dagger}$, Xiaolei Song $^{\dagger}$, Bachchu Lal $^{\ddagger}$, Xing Yang $^{\dagger}$, Martin \\ Pomper $^{\dagger}$, John Laterra ${ }^{\ddagger}$, Sridhar Nimmagadda ${ }^{*}$, , and Michael T. McMahon ${ }^{*}, \dagger, \S$ \\ †Russell H. Morgan Department of Radiology and Radiological Science, The Johns Hopkins \\ University School of Medicine, Baltimore, Maryland 21287, United States \\ ‡Department of Neurology, The Johns Hopkins University School of Medicine, Baltimore, \\ Maryland 21287, United States \\ §F.M. Kirby Research Center for Functional Brain Imaging, Kennedy Krieger Institute, Baltimore, \\ Maryland 21287, United States
}

\begin{abstract}
Chemical exchange saturation transfer (CEST) is a novel MRI contrast mechanism that is well suited for imaging, however, existing small molecule CEST agents suffer from low sensitivity. We have developed salicylic acid conjugated dendrimers as a versatile, high performance nanoplatform. In particular, we have prepared nanocarriers based on generation 5poly(amidoamine) (PAMAM) dendrimers with salicylic acid covalently attached to their surface. The resulting conjugates produce strong CEST contrast $9.4 \mathrm{ppm}$ from water with the proton exchange tunable from $\sim 1000 \mathrm{~s}^{-1}$ to $\sim 4500 \mathrm{~s}^{-1}$ making these dendrimers well suited for sensitive detection. Furthermore, we demonstrate that these conjugates can be used for monitoring convection enhanced delivery into U87 glioblastoma bearing mice, with the contrast produced by these nanoparticles persisting for over $1.5 \mathrm{~h}$ and distributed over $\sim 50 \%$ of the tumors. Our results demonstrate that SA modified dendrimers present a promising new nanoplatform for medical applications.
\end{abstract}

\section{Graphical abstract}

\footnotetext{
*Corresponding Authors:; Email: mtmcmaho@gmail.com; ; Email: snimmag1@jhmi.edu

Supporting Information

The Supporting Information is available free of charge on the ACS Publications website at DOI: 10.1021/acs.nano-lett.5b04517.

Experimental details and data. (PDF)

Author Contributions

The manuscript was written through contributions of all authors. All authors have given approval to the final version of the manuscript. W.L., N.O., M.M., and S.N. planned and designed this study and wrote the draft. W.L. synthesized and characterized the dendrimer conjugates. N.O. and M.M. performed the in vitro and in vivo MRI measurements and processed the data. X.S. wrote the imaging sequence in ParaVision and image processing code in Matlab. B.L. implanted the U87 cells and performed the intracranial infusion of dendrimer under J.L.'s supervision. The draft was edited by J.L., X.Y., and M.P.

Notes

The authors declare the following competing financial interest(s): Dr. McMahon is a co-founder of and holds an equity ownership in a startup company, SenCEST, LLC. Some of the methodologies presented in this paper may ultimately become part of a SenCEST product. This arrangement has been reviewed and approved by the Johns Hopkins University in accordance with its conflict of interest policies.
} 


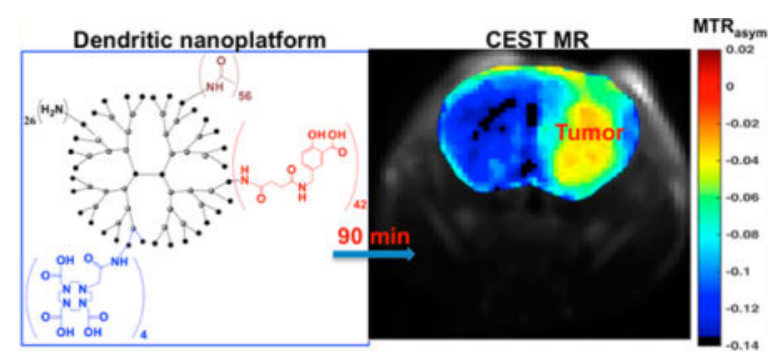

\section{Keywords}

dendrimers; glioblastoma; salicylic acid; chemical exchange saturation transfer (CEST); CED

CEST imaging is rapidly emerging as a novel MRI contrast mechanism that is useful for molecular imaging. ${ }^{1}{ }^{3}$ CEST possesses several benefits compared to other MRI contrast mechanisms. Frequency-specific switchable contrast could be achieved by CEST (turned "on" through application of saturation pulse). Thus, detection of multiple agents independently in a single image is possible similar to that achieved with optical imaging agents. ${ }^{14}$ Because of its reliance on exchangeable protons, CEST can be applied for detecting organic compounds and probe biochemical pathways based on biomolecule's inherent CEST properties. ${ }^{5}$ Several examples of this include glucose, ${ }^{6}{ }^{9}$ glycogen, ${ }^{10}$ glutamate, ${ }_{11}^{11}$ L-arginine ${ }_{12}^{12}$ creatine, ${ }^{13},{ }^{14}$ barbituric acid, ${ }^{15}$ a number of thymidine analogs, ${ }^{16}$ iopamidol, ${ }^{17}$ iopromide, ${ }^{18}$ glycosaminoglycans, ${ }^{19}$ and proteins such as the lysine rich protein, human protamine, and others. ${ }^{20} 23$ Many existing CEST imaging agents exhibit low sensitivity caused by a small difference in chemical shift for their exchangeable protons with water and high concentration metabolites. As a solution, we have reported salicylic acid (SA), anthranillic acid and number of their derivatives as organic, diamagnetic CEST agents with highly shifted exchangeable protons (between 5 and $12 \mathrm{ppm}$ from water), which present sensitivity advantages for $3 \mathrm{~T}$ clinical scanners. ${ }^{24 \_26}$ We were interested in translating these probes for monitoring nanocarrier delivery.

Brain tumors, particularly glioblastoma multiforme, have poor survival rates even with use of the most aggressive therapies. ${ }^{27}$ Therapeutic options for brain tumors are limited by insufficient delivery of systemically administered agents to tumor. ${ }^{28}$ Convection-enhanced delivery (CED) is gaining attention as a local therapeutic delivery option for nanocarriers, particularly for brain tumors due to the possibility of a prolonged, high payload delivery. ${ }^{29}$ Though macro distribution (accumulation, retention, and clearance) properties of nanoparticles within brain tumors can be quantified using PET and optical imaging techniques noninvasively, their micro distribution (rate and extent of distribution within the tumor) is difficult to monitor using these imaging techniques due to poor spatial resolution and depth penetration, respectively. We surmised that the high spatial resolution and functional aspects of CEST MR could be used to noninvasively image the distribution of nanoparticles within brain tumors. ${ }^{30}$ As dendrimers have emerged as a versatile platform for drug and gene delivery ${ }^{31,32}$ and proven useful for delivering therapeutics to brain tumors via CED, ${ }^{33} 35$ herein we have used CEST MR to investigate dendrimer distribution after CED to brain tumors. In order to accomplish this, we have prepared SA conjugated dendrimers 
with different functional end groups. We have evaluated their capabilities in vivo in mice bearing U87 glioblastoma xenografts.

To perform this proof of concept study, we have utilized poly(amidoamine) (PAMAM) dendrimers, ${ }^{36}$ which have been extensively studied in combination with radionuclides, ${ }^{37,38}$ fluorescent dyes, ${ }^{39} \mathrm{Gd}(\mathrm{III})$ chelates, ${ }^{40,41}$ and therapeutics. ${ }^{42}$ In particular, we have conjugated a large number of SA in order to render these detectable via CEST MRI and have modified the surface further to fine-tune their contrast. We selected 5-aminomethyl SA as a CEST contrast agent to conjugate to dendrimers because of its near optimal exchange rate for detection on our $3 \mathrm{~T}$ scanners, commercial availability and low price. SA was conjugated to PAMAM generation 5 amine terminated dendrimer with 126 terminal $\mathrm{NH}_{2}$ groups (G5$\mathrm{Am}$ ) that can be readily modified and possesses favorable fast renal clearance due to its $\sim 5$ $\mathrm{nm}$ size. ${ }^{40}$ We first investigated the changes in dendrimer solubility following SA conjugation. We prepared dendrimers with different number of SA: G5 -SA $42-\mathrm{Am}, \mathrm{G} 5$ $\mathrm{SA}_{50}-\mathrm{Am}$, and $\mathrm{G} 5-\mathrm{SA}_{60}-\mathrm{Am}$ through changing the molar ratio of dendrimer and salicylic acid for conjugation and allowing for sufficient SA concentration for MR detection. Of these, only G5-SA 42 -dendrimer showed suitable solubility in PBS to achieve a $360 \mu \mathrm{M}$ concentration that is required for MR detection. Using that G5- $\mathrm{SA}_{42}-\mathrm{Am}$ as a parent dendrimer, we conjugated two DOTA molecules (D) for radiolabeling and future PET/MR studies and capped the remaining terminal primary amines with acetyl or 1,2-propanediol functionalities to modulate surface properties (Scheme 1). These modifications resulted in amine-, acetyl-, and diol-functionalized end group nanocarriers. After each synthesis step the resulting conjugates were comprehensively characterized and numbers of terminal functionalities were calculated based on results obtained from ${ }^{1} \mathrm{H}$ NMR, MALDI-TOF and UV-vis spectroscopy (for details see Supporting Information). We surmised that different terminal groups of dendrimers will have different surface properties and will impact the exchange rates $\left(k^{\prime} \mathrm{s}\right)$ and perhaps the distribution of dendrimer within tissue. An additional advantage is a reduced overall positive charge that contributes to toxicity observed with dendrimers. ${ }^{30}$

The three G5 based nanoparticles shown in Scheme 1 (360 $\mu \mathrm{M}$ solutions, $~ 15 \mathrm{mM}$ in SA residues) were then tested for CEST MRI contrast properties. Exchangeable protons present on these nanoplatforms include surface phenols, surface amines, and surface glycidols as well as interior tertiary/secondary amines. We acquired saturation transfer spectra as a function of saturation power to measure the $k_{\mathrm{ex}}$ 's for these compounds. As expected, all three dendrimer conjugates produced frequency-dependent CEST contrast with a main peak at $9.4 \mathrm{ppm}$ and additional peaks at 3.6 and $2.2 \mathrm{ppm}$ from the chemical shift of water. These peaks also increased in amplitude when stronger saturation pulses were used (Figure $1 \mathrm{~A}, \mathrm{~B}, \mathrm{C})$. On the basis of the breadth of the contrast peaks, it is evident that the phenolic protons (9.4 ppm) exchange slowest in the G5-SA-D-Ac conjugate and fastest in the G5-SAD-Am conjugate. To quantify this, we fit the saturation power intensity data as described previously ${ }^{25,43}$ and display the resulting fits in Figure 1D and tabulate the exchange rates $\left(k_{\mathrm{ex}}\right)$ for the phenolic protons determined in Table 1. On the basis of examining the saturation field dependence, which revealed relatively rapid exchange, we fit the data by solving the Bloch equations numerically to avoid underestimation. The phenolic protons in G5-SA-D-Ac possess a 4.5 times slower $k_{\mathrm{ex}}$ compared to G5-SAD-Am, with $k_{\mathrm{ex}}$ rates of 
$950 \mathrm{~s}^{-1}$ and $4500 \mathrm{~s}^{-1}$, respectively. This data demonstrates the inductive effects of the neighboring amines and hydroxyls on phenolic - $\mathrm{OH}$ exchange, which is similar to effects observed in peptides originally described by Molday and co-workers. ${ }^{44}$ From our data, it is evident that sensitivity of the SA dendrimer is enhanced for CEST imaging after conjugation of SA to the dendrimer due to maintaining a favorable $k_{\mathrm{ex}}$, compared to the previously reported SA monomer. ${ }^{25}$ Further testing validated that this contrast is maintained in blood plasma (Supporting Information, Figure S9). Overall, the G5-SA-D-Ac dendrimer displayed the highest sensitivity for $\omega_{1}<5.9 \mu \mathrm{T}$ and also the sharpest frequency dependence, making it the most promising CEST agent for use in $3 \mathrm{~T}$ clinical scanners. We also measured the size and zeta potential of the final nanoparticles that could impact in vivo distribution and compared these measurements with unmodified starting dendrimer. The zeta potential values gradually decreased from $+43.5 \mathrm{mV}$ for G5Am (fully amine terminated $=$ starting dendrimer) to $+22.03,+11.15$, and $-6.91 \mathrm{mV}$ for G5-SA-D-Am, G5-SA-D-Diol, and G5SA-D-Ac, respectively. In agreement with measured number of 1,2-propanediol and acetamide groups in the G5-SA-D-Diol and G5-SA-D-Ac dendrimers, respectively, zeta potential analysis indicated that they are not fully capped even though a $10 \times$ molar excess of glycidol and acetic anhydride over the free surface amines was used for the capping reactions. It is likely that steric hindrance imposed by SA, DOTA, and Diol or Ac surfacefunctional groups impedes the complete substitution of all terminal amines. This observation is consistent with previously reported results, indicating that complete substitution of terminal groups in high generation dendrimer is not feasible due to steric crowding. ${ }^{45}$ Dynamic light scattering measurements reveal that the size distributions for all G5 nanocarriers remained narrow and centered around $\sim 5 \mathrm{~nm}$. On the basis of the strongest CEST contrast (using $\mathrm{B}_{1}=0-6 \mu \mathrm{T}$ ), the sharpness of the frequency profile in the Z-spectra, and the smallest zeta potential observed, we chose the G5-SA-D-Ac dendrimers for in vivo imaging.

To examine the distribution properties of G5-SA-D-Ac, we delivered CEST nanocarriers based on convection enhanced delivery (CED), ${ }^{46}$ which is efficient for delivery of both macromolecules and nanocarriers ${ }^{47} 50$ and involves pressurized infusion directly into a tumor. SCID mice were inoculated with U87 glioblastoma cells in right caudate putamen under stereotaxic control. The infusions of CEST nanocarriers were performed through the same site as the tumor inoculation site. A control group of two mice was infused with PBS using the same procedure. These infusions were followed by CEST and $\mathrm{T}_{2 \mathrm{w}}$ MRI.

Representative images of average MTR $_{\text {asym }}$ from 8.7 to 9.9 ppm acquired preinjection and at 30 and 60 min after injection of dendrimer are displayed in Figure 2. In Figure 3A, we plot the relative $\mathrm{MTR}_{\text {asym }}$ spectra at $60 \mathrm{~min}$ after injection of both dendrimer and PBS as control for an ROI enclosing the tumor region. These CEST MR images and relative MTR $_{\text {asym }}$ spectra depict up to $11 \%$ contrast after infusion.

The distribution of nanocarrier within tumors is an important factor to determine following CED. As seen in Figure 2, the distribution in average MTR $_{\text {asym }}$ values over the whole brain tumor was less than -0.035 prior to CED. In contrast, there was a significant fraction of tumor pixels with elevated contrast after the injection of G5-D-SA-Ac dendrimer. Also, as shown in Supporting Information (Figure S8), this contrast persisted for $1.5 \mathrm{~h}$. Additionally, we borrowed the concept of target coverage concept used in radiation therapy to calculate 
the dendrimer coverage of the brain tumors. ${ }^{51,52}$ Assuming all contrast greater than -0.035 is due to the CEST agent, our data show that $50 \%$ of the tumor pixels contain G5-SA-D-Ac dendrimer conjugate for $n=3$ mice which contrasts with the $\sim 2 \%$ calculated for the control PBS infusion ( $n=2$ mice) (Figure 3B). These measurements indicate that this dendrimer was well detected (contrast $>5 \%$ ) and widely dispersed within brain tumors using an infusion rate of $0.5 \mu \mathrm{L} / \mathrm{min}$, which is recommended for rodents and similar to the flow rates used in patients previously. 47

As shown by our data, we have prepared and tested a novel PAMAM dendrimer based diamagnetic nanoplatform that produces CEST MRI contrast. Previously, dendritic gadolinium, europium, yterbium, and dysprosium chelates have been prepared as high sensitivity MRI agents and have displayed favorable pharmacokinetics for use as blood pool agents, lymphatic imaging agents, liver imaging agents, and renal function agents. ${ }^{53 \_61}$ The new SA based PAMAM dendrimers present additional advantages based on the MRI contrast being produced by SA, a metabolite of aspirin which has been used as an antiinflammatory drug in patients, ${ }^{62} 64$ and the neutralization of the dendrimer surface, which might influence biodistribution. ${ }^{65}$ In addition, conjugation of SA together with chemotherapeutics and neutralizing agents targeting brain tumor specific proteins (e.g., EGFR, CXCR4, or integrins) have the potential for improved retention of dendrimers within tumors and augmented therapeutic effects. Though previously we demonstrated that dendrimers could be detected without modification using CEST MRI, ${ }^{43}$ the sensitivity was modest. In this study, infusion of $5 \mu \mathrm{L}$ of $500 \mu \mathrm{M}$ dendrimer solution into mice allowed detection. On the basis of our results, a factor of 3 lower in concentration would also be expected to be detectable. Lower detection limits could be achieved using improved scanner hardware and image acquisition schemes. We expect that the dendrimer based nanocarriers evaluated herein have the sensitivity to enable usage on clinical $3 \mathrm{~T}$ scanners based on their larger shifts compared to other agents. Finally, the presence of DOTA on PAMAM dendrimers will allow for dual-or multi- modality PET/SPECT/MR imaging. Our ability to noninvasively characterize nanoparticle tumor distribution may allow for design of nanotherapeutics with improved intratumoral diffusion properties.

In summary, we have designed and synthesized SA-based nanocarriers, which produce excellent characteristics as CEST agents, that is, large chemical shift $=9.4 \mathrm{ppm}$ from water and exchange rates from 1000 to $4500 \mathrm{~s}^{-1}$. We demonstrate that these are readily detected in vivo in mice bearing U87 glioblastoma brain tumors with stable contrast up to $1.5 \mathrm{~h}$ after intracranial injection.

\section{METHODS}

Details on conjugation chemistry, NMR, MALDI-TOF, DLS, UV-vis analysis, and in vitro and in vivo MRI measurements are provided in the Supporting Information.

\section{Supplementary Material}

Refer to Web version on PubMed Central for supplementary material. 


\section{Acknowledgments}

Funding was provided by NIH R01EB015031, R01CA16631, P30CA006973, P50CA103175, U54CA151838, S10RR025118.

\section{References}

1. McMahon MT, Gilad AA, DeLiso MA, Berman SM, Bulte JW, van Zijl PC. Magn Reson Med. 2008; 60:803-12. [PubMed: 18816830]

2. Chan KW, Bulte JW, McMahon MT. Wiley Interdiscip Rev: Nanomed Nanobiotechnol. 2014; 6:111-24. [PubMed: 24339357]

3. Liu G, Moake M, Har-el YE, Long CM, Chan KW, Cardona A, Jamil M, Walczak P, Gilad AA, Sgouros G, van Zijl PC, Bulte JW, McMahon MT. Magn Reson Med. 2012; 67:1106-13. [PubMed: 22392814]

4. Aime S, Carrera C, Delli Castelli D, Geninatti Crich S, Terreno E. Angew Chem, Int Ed. 2005; 44:1813-1815.

5. Bartolini ME, Pekar J, Chettle DR, McNeill F, Scott A, Sykes J, Prato FS, Moran GR. Magn Reson Imaging. 2003; 21:541-4. [PubMed: 12878264]

6. Walker-Samuel S, Ramasawmy R, Torrealdea F, Rega M, Rajkumar V, Johnson SP, Richardson S, Goncalves M, Parkes HG, Arstad E, Thomas DL, Pedley RB, Lythgoe MF, Golay X. Nat Med. 2013; 19:1067-1072. [PubMed: 23832090]

7. Chan KWY, McMahon MT, Kato Y, Liu G, Bulte JWM, Bhujwalla ZM, Artemov D, van Zijl PCM. Magn Reson Med. 2012; 68:1764-1773. [PubMed: 23074027]

8. Rivlin M, Tsarfaty I, Navon G. Magn Reson Med. 2014; 72:1375-1380. [PubMed: 25236979]

9. Jin T, Mehrens H, Hendrich KS, Kim SG. J Cereb Blood Flow Metab. 2014; 34:1402-1410. [PubMed: 24865996]

10. van Zijl PC, Jones CK, Ren J, Malloy CR, Sherry AD. Proc Natl Acad Sci U S A. 2007; 104:4359_ 4364. [PubMed: 17360529]

11. Kogan F, Singh A, Debrosse C, Haris M, Cai K, Nanga RP, Elliott M, Hariharan H, Reddy R. NeuroImage. 2013; 77:262-267. [PubMed: 23583425]

12. Chan KW, Liu G, Song X, Kim H, Yu T, Arifin DR, Gilad AA, Hanes J, Walczak P, van Zijl PC, Bulte JW, McMahon MT. Nat Mater. 2013; 12:268-275. [PubMed: 23353626]

13. Kogan F, Haris M, Singh A, Cai K, Debrosse C, Nanga RP, Hariharan H, Reddy R. Magn Reson Med. 2014; 71:164-72. [PubMed: 23412909]

14. Sun PZ, Benner T, Kumar A, Sorensen AG. Magn Reson Med. 2008; 60:834-841. [PubMed: 18816867]

15. Chan KW, Yu T, Qiao Y, Liu Q, Yang M, Patel H, Liu G, Kinzler KW, Vogelstein B, Bulte JW, van Zijl PC, Hanes J, Zhou S, McMahon MT. J Controlled Release. 2014; 180:51-59.

16. Bar-Shir A, Liu GS, Liang YJ, Yadav NN, McMahon MT, Walczak P, Nimmagadda S, Pomper MG, Tallman KA, Greenberg MM, van Zijl PCM, Bulte JWM, Gilad AA. J Am Chem Soc. 2013; 135:1617-1624. [PubMed: 23289583]

17. Longo DL, Busato A, Lanzardo S, Antico F, Aime S. Magn Reson Med. 2013; 70:859-864. [PubMed: 23059893]

18. Chen LQ, Howison CM, Jeffery JJ, Robey IF, Kuo PH, Pagel MD. Magn Reson Med. 2014; 72:1408-1417. [PubMed: 24281951]

19. Ling W, Regatte RR, Navon G, Jerschow A. Proc Natl Acad Sci U S A. 2008; 105:2266-2270. [PubMed: 18268341]

20. Bar-Shir A, Liu G, Chan KWY, Oskolkov N, Song X, Yadav NN, Walczak P, McMahon MT, van Zijl PCM, Bulte JWM, Gilad AA. ACS Chem Biol. 2014; 9:134-138. [PubMed: 24138139]

21. Farrar CT, Buhrman JS, Liu GS, Kleijn A, Lamfers MLM, McMahon MT, Gilad AA, Fulci G. Radiology. 2015; 275:746-754. [PubMed: 25686366]

22. Gilad AA, McMahon MT, Walczak P, Winnard PT, Raman V, van Laarhoven HWM, Skoglund CM, Bulte JWM, van Zijl PCM. Nat Biotechnol. 2007; 25:217-219. [PubMed: 17259977] 
23. Zhou JY, Lal B, Wilson DA, Laterra J, van Zijl PCM. Magn Reson Med. 2003; 50:1120-1126. [PubMed: 14648559]

24. Yang X, Song X, Li Y, Liu G, Ray Banerjee S, Pomper MG, McMahon MT. Angew Chem, Int Ed. 2013; 52:8116-8119.

25. Yang X, Yadav NN, Song X, Ray Banerjee S, Edelman H, Minn I, van Zijl PC, Pomper MG, McMahon MT. Chem - Eur J. 2014; 20:15824-15832. [PubMed: 25302635]

26. Song X, Airan RD, Arifin DR, Bar-Shir A, Kadayakkara DK, Liu G, Gilad AA, van Zijl PC, McMahon MT, Bulte JW. Nat Commun. 2015; 6:6719. [PubMed: 25813863]

27. Thomas AA, Brennan CW, DeAngelis LM, Omuro AM. JAMA Neurol. 2014; 71:1437-1444. [PubMed: 25244650]

28. Woodworth GF, Dunn GP, Nance EA, Hanes J, Brem H. Front Oncol. 2014; 4:126. [PubMed: 25101239]

29. Vogelbaum MA, Aghi MK. Neuro-Oncology. 2015; 17:II3-II8. [PubMed: 25746090]

30. Kogan F, Hariharan H, Reddy R. Curr Radiol Rep. 2013; 1:102-114. [PubMed: 23730540]

31. Caminade AM, Turrin CO. J Mater Chem B. 2014; 2:4055-4066.

32. Somani S, Dufes C. Nanomedicine. 2014; 9:2403-2414. [PubMed: 25413857]

33. Yang WL, Barth RF, Wu G, Huo TY, Tjarks W, Ciesielski M, Fenstermaker RA, Ross BD, Wikstrand CJ, Riley KJ, Binns PJ. J Neuro-Oncol. 2009; 95:355-365.

34. Agrawal A, Min DH, Singh N, Zhu HH, Birjiniuk A, von Maltzahn G, Harris TJ, Xing DY, Woolfenden SD, Sharp PA, Charest A, Bhatia S. ACS Nano. 2009; 3:2495-2504. [PubMed: 19673534]

35. Yang WL, Wu G, Barth RF, Swindall MR, Bandyopadhyaya AK, Tjarks W, Tordoff K, Moeschberger M, Sferra TJ, Binns PJ, Riley KJ, Ciesielski MJ, Fenstermaker RA, Wikstrand CJ. Clin Cancer Res. 2008; 14:883-891. [PubMed: 18245552]

36. Esfand R, Tomalia DA. Drug Discovery Today. 2001; 6:427-436. [PubMed: 11301287]

37. Almutairi A, Rossin R, Shokeen M, Hagooly A, Ananth A, Capoccia B, Guillaudeu S, Abendschein D, Anderson CJ, Welch MJ, Frechet JMJ. Proc Natl Acad Sci U S A. 2009; 106:685690. [PubMed: 19129498]

38. Zhang YQ, Sun YH, Xu XP, Zhu H, Huang LL, Zhang XZ, Qi YJ, Shen YM. Bioorg Med Chem Lett. 2010; 20:927-931. [PubMed: 20045643]

39. Kobayashi H, Koyama Y, Barrett T, Hama Y, Regino CAS, Shin IS, Jang BS, Le N, Paik CH, Choyke PL, Urano Y. ACS Nano. 2007; 1:258-264. [PubMed: 19079788]

40. Villaraza AJL, Bumb A, Brechbiel MW. Chem Rev. 2010; 110:2921-2959. [PubMed: 20067234]

41. Opina AC, Wong KJ, Griffiths GL, Turkbey BI, Bernardo M, Nakajima T, Kobayashi H, Choyke PL, Vasalatiy O. Nanomedicine. 2015; 10:1423-1437. [PubMed: 25392239]

42. Menjoge AR, Kannan RM, Tomalia DA. Drug Discovery Today. 2010; 15:171-185. [PubMed: 20116448]

43. McMahon MT, Gilad AA, Zhou J, Sun PZ, Bulte JW, van Zijl PC. Magn Reson Med. 2006; 55:836-847. [PubMed: 16506187]

44. Molday RS, Englander SW, Kallen RG. Biochemistry. 1972; 11:150-158. [PubMed: 5061873]

45. Talanov VS, Regino CAS, Kobayashi H, Bernardo M, Choyke PL, Brechbiel MW. Nano Lett. 2006; 6:1459-1463. [PubMed: 16834429]

46. Bobo RH, Laske DW, Akbasak A, Morrison PF, Dedrick RL, Oldfield EH. Proc Natl Acad Sci U S A. 1994; 91:2076-2080. [PubMed: 8134351]

47. Allard E, Passirani C, Benoit JP. Biomaterials. 2009; 30:2302-2318. [PubMed: 19168213]

48. Bidros DS, Liu JK, Vogelbaum MA. Future Oncol. 2010; 6:117-125. [PubMed: 20021213]

49. Zhou J, Atsina KB, Himes BT, Strohbehn GW, Saltzman WM. Cancer J. 2012; 18:89-99. [PubMed: 22290262]

50. Lonser RR, Walbridge S, Garmestani K, Butman JA, Walters HA, Vortmeyer AO, Morrison PF, Brechbiel MW, Oldfield EH. J Neurosurg. 2002; 97:905-913. [PubMed: 12405380]

51. Shaw E, Kline R, Gillin M, Souhami L, Hirschfeld A, Dinapoli R, Martin L. Int J Radiat Oncol, Biol Phys. 1993; 27:1231-1239. [PubMed: 8262852] 
52. Stroom JC, de Boer HC, Huizenga H, Visser AG. Int J Radiat Oncol, Biol Phys. 1999; 43:905-919. [PubMed: 10098447]

53. Kobayashi H, Brechbiel MW. Adv Drug Delivery Rev. 2005; 57:2271-2286.

54. Toth E, Pubanz D, Vauthey S, Helm L, Merbach AE. Chem - Eur J. 1996; 2:1607-1615.

55. Wiener EC, Brechbiel MW, Brothers H, Magin RL, Gansow OA, Tomalia DA, Lauterbur PC. Magn Reson Med. 1994; 31:1-8. [PubMed: 8121264]

56. Bryant LH, Brechbiel MW, Wu CC, Bulte JWM, Herynek V, Frank JA. J Magn Reson Imag. 1999; 9:348-352.

57. Misselwitz B, Schmitt-Willich H, Ebert W, Frenzel T, Weinmann HJ. Magn Reson Mat Phys Biol Med. 2001; 12:128-134.

58. Bulte JWM, Wu CC, Brechbiel MW, Brooks RA, Vymazal J, Holla M, Frank JA. Invest Radiol. 1998; 33:841-845. [PubMed: 9818319]

59. Huang CH, Nwe K, Al Zaki A, Brechbiel MW, Tsourkas A. ACS Nano. 2012; 6:9416-9424. [PubMed: 23098069]

60. Ali MM, Bhuiyan MPI, Janic B, Varma NRS, Mikkelsen T, Ewing JR, Knight RA, Pagel MD, Arbab AS. Nanomedicine. 2012; 7:1827-1837. [PubMed: 22891866]

61. Pikkemaat JA, Wegh RT, Lamerichs R, van de Molengraaf RA, Langereis S, Burdinski D, Raymond AYF, Janssen HM, de Waal BFM, Willard NP, Meijer EW, Grull H. Contrast Media Mol Imaging. 2007; 2:229-239. [PubMed: 17937448]

62. Needs CJ, Brooks PM. Clin Pharmacokinet. 1985; 10:164-177. [PubMed: 3888490]

63. Bochner F, Graham GG, Cham BE, Imhoff DM, Haavisto TM. Clin Pharmacol Ther. 1981; 30:266-275. [PubMed: 7249509]

64. Paterson JR, Baxter G, Dreyer JS, Halket JM, Flynn R, Lawrence JR. J Agric Food Chem. 2008; 56:11648-11652. [PubMed: 19053387]

65. Shcharbin D, Janaszewska A, Klajnert-Maculewicz B, Ziemba B, Dzmitruk V, Halets I, Loznikova S, Shcharbina N, Milowska K, Ionov M, Shakhbazau A, Bryszewska M. J Controlled Release. 2014; 181:40-52. 

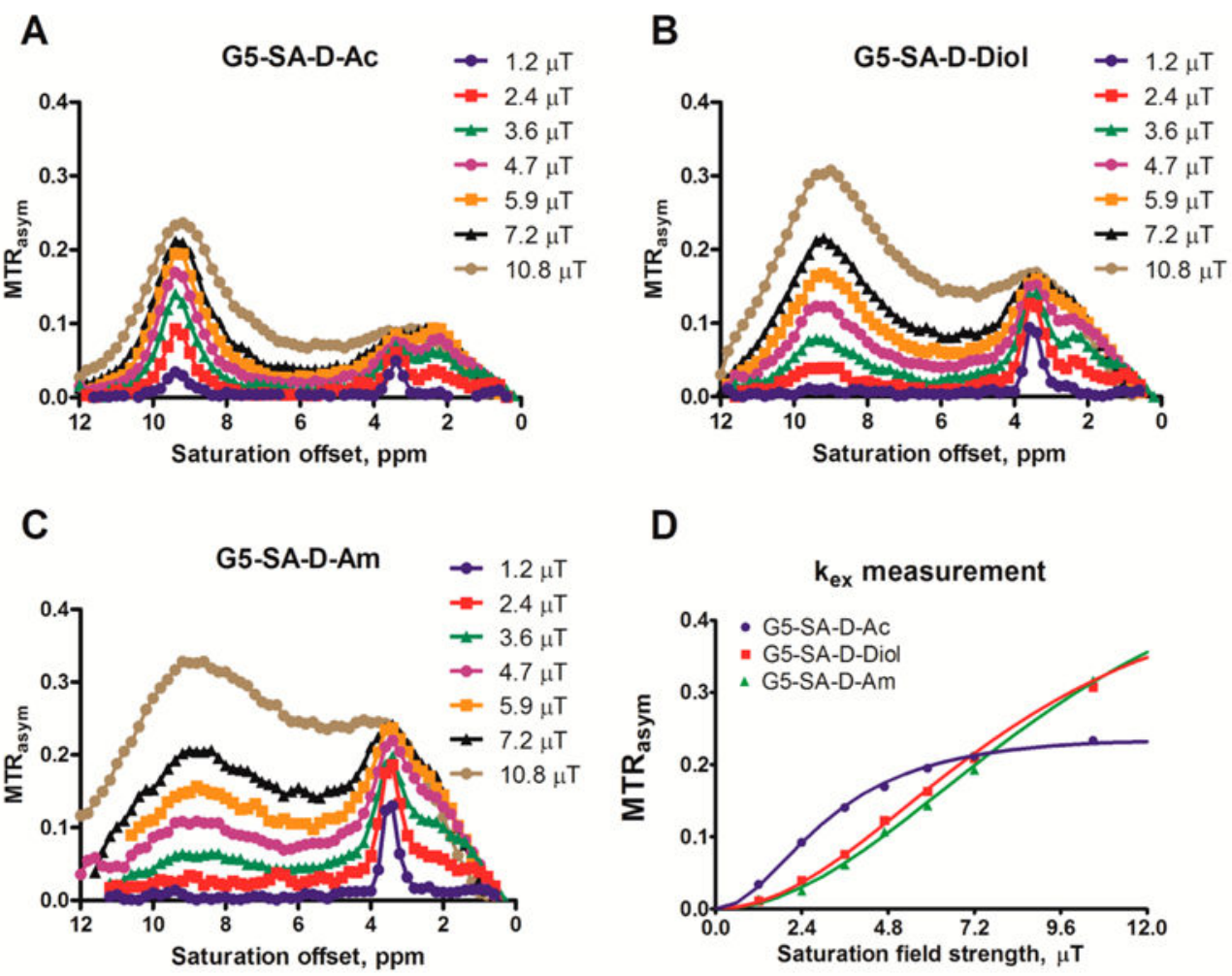

Figure 1.

MTR $_{\text {asym }}$ of CEST-based dendrimer conjugates with different surface properties, (A) acetylated, (B) hydroxylated, and (C) amino-terminated. (D) Exchange rate constant $k_{\mathrm{ex}}$ calculation of protons in salicylic acid residues of CEST dendritic nanoparticles using QUESP method. 
$\mathbf{T}_{2 \mathrm{w}}$

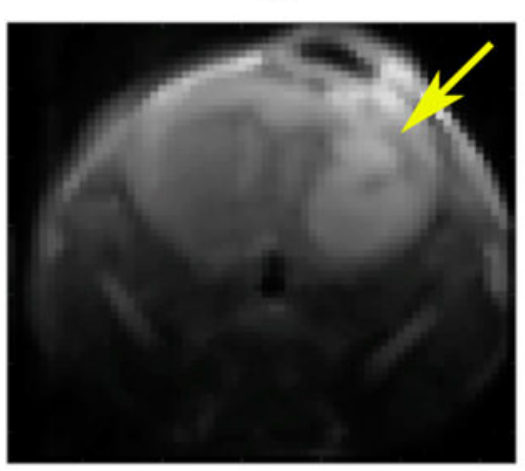

Post $30 \mathrm{~min}$

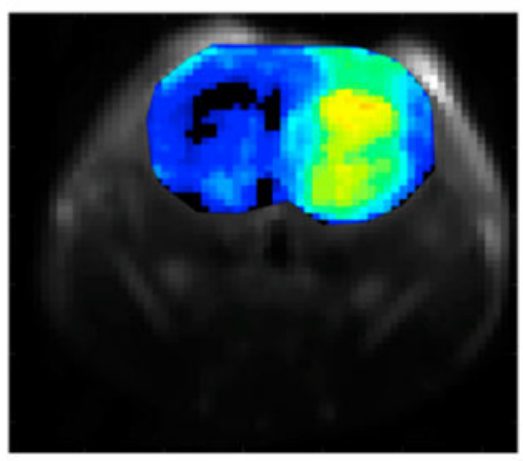

Pre-injection

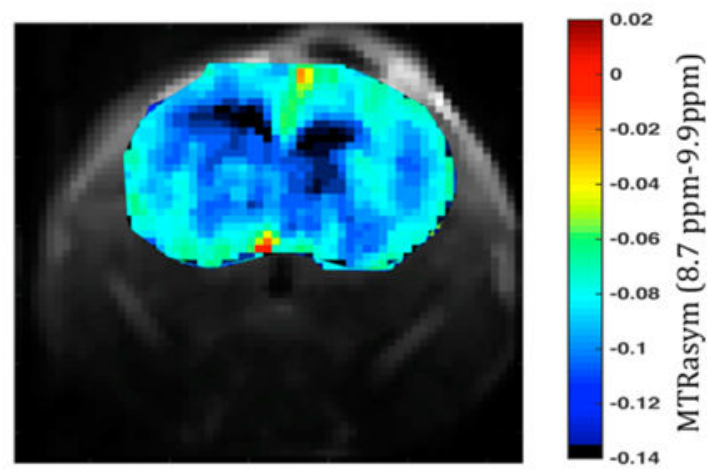

Post 60 min

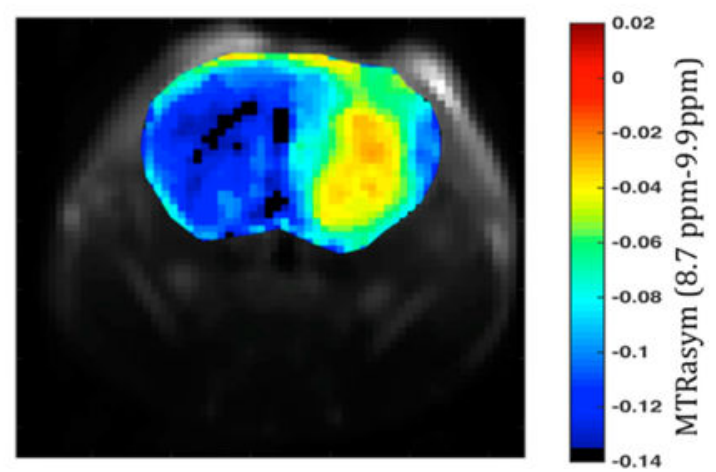

Figure 2.

In vivo CEST images were calculated as an average of MTR $_{\text {asym }}$ from 8.7 to $9.9 \mathrm{ppm}$ from water and were acquired pre-intratumoral infusion and 30 and $60 \mathrm{~min}$ postintratumoral infusion of $500 \mu \mathrm{M}$ solutions of G5-SA-D-Ac conjugates into U87 glioblastoma xenografts in SCID mice. MRI data, G5-SA-D-Ac dendrimer conjugates can be detected via CEST contrast within the tumor. The yellow arrow highlights tumor location. 

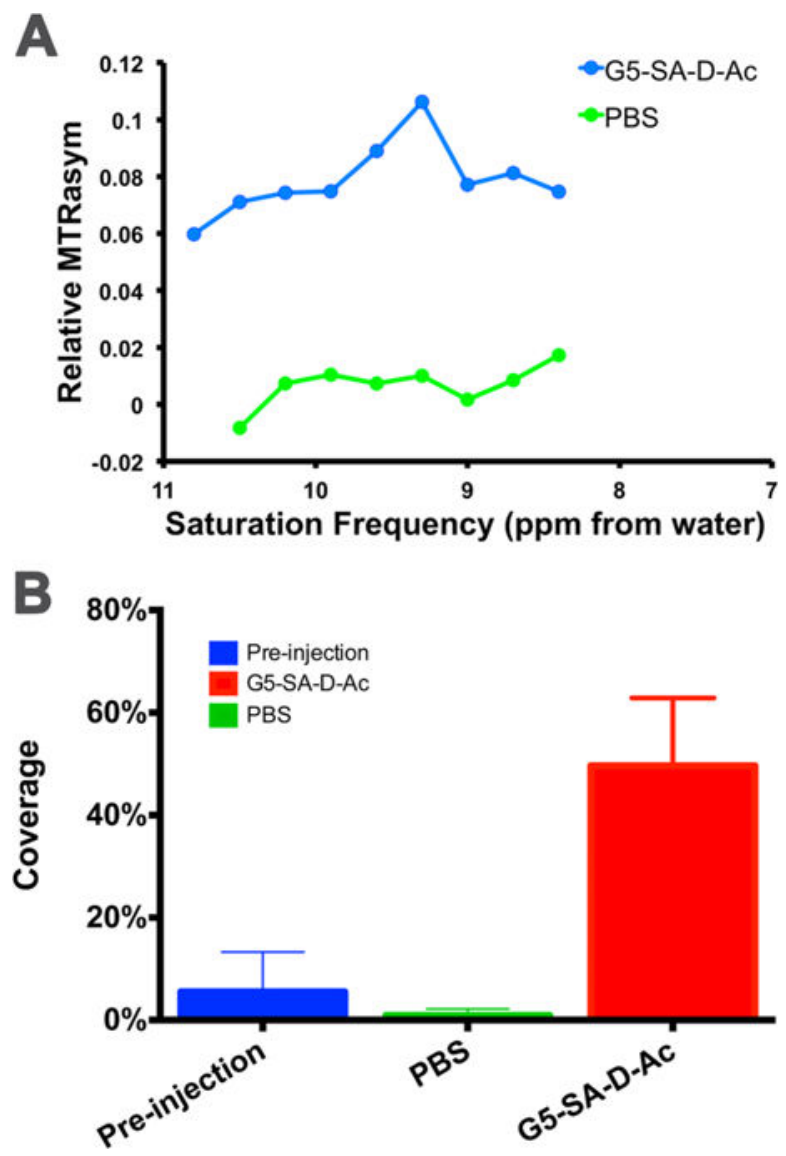

Figure 3.

(A) Relative $\mathrm{MTR}_{\text {asym }}$ spectra for an ROI enclosing the brain tumor at $60 \mathrm{~min}$ postintratumoral infusion of G5-SA-D-Ac dendrimer and control PBS (B) \% of tumor covered assuming pixels with MTR $_{\text {asym }} \geq-0.035$ contain G5-SA-D-Ac dendrimer. 
A

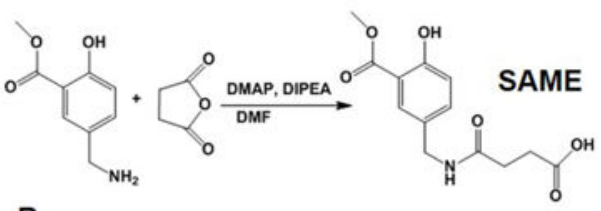

SAME
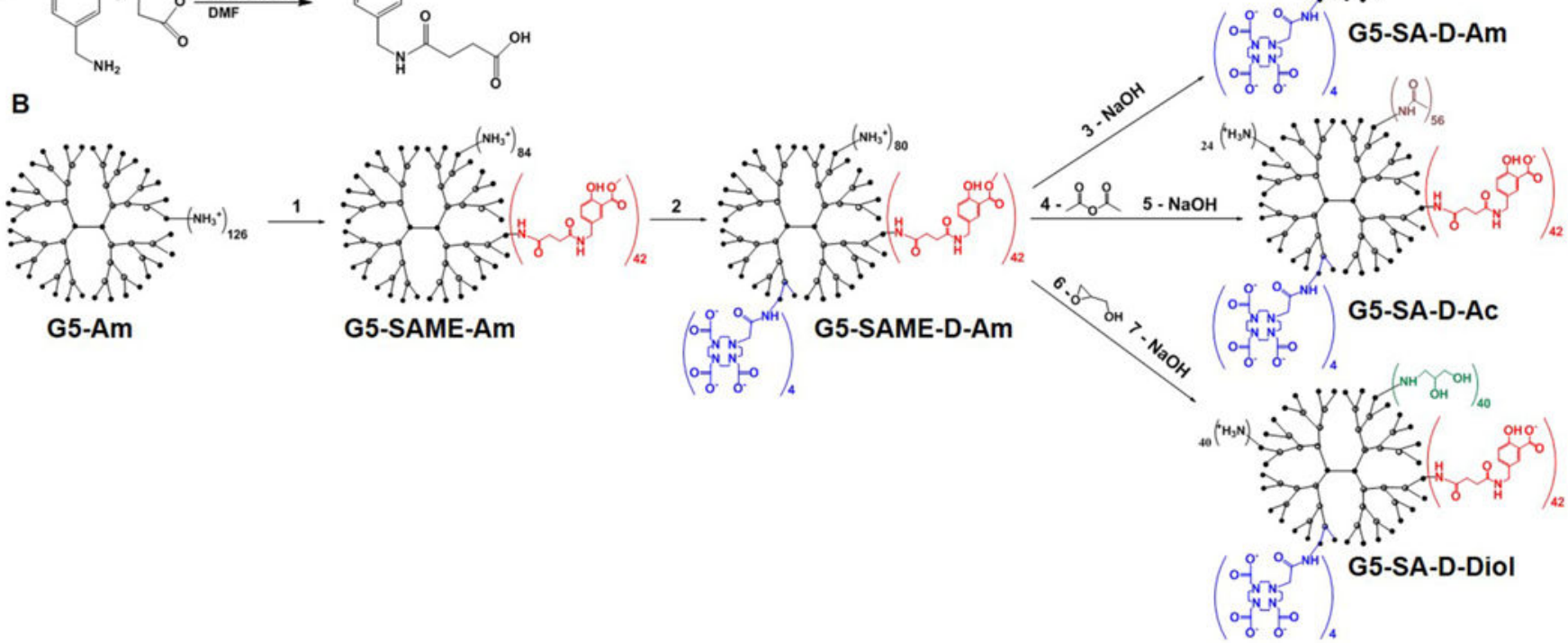

Scheme 1.

(A) Step Involved in Carboxylation of 5-Aminomethylsalicylic Acid Methyl Ester (SAME) and (B) Schematic Pathway for Preparation of Dendrimers with Different Functional Groups $^{a}$

${ }^{a}$ G5-Am, generation (5) PAMAM dendrimer; SAME, 5- $N$-succinamylmethylsalicylic acid methyl ester; D, DOTA; Ac, acetyl; Diol, 1,2-propanediol. Numbers of conjugated functional groups were determined by combination of ${ }^{1}$ HNMR, MALDI-TOF, and UV-vis spectroscopy (for details see Supporting Information). 


\section{롤}

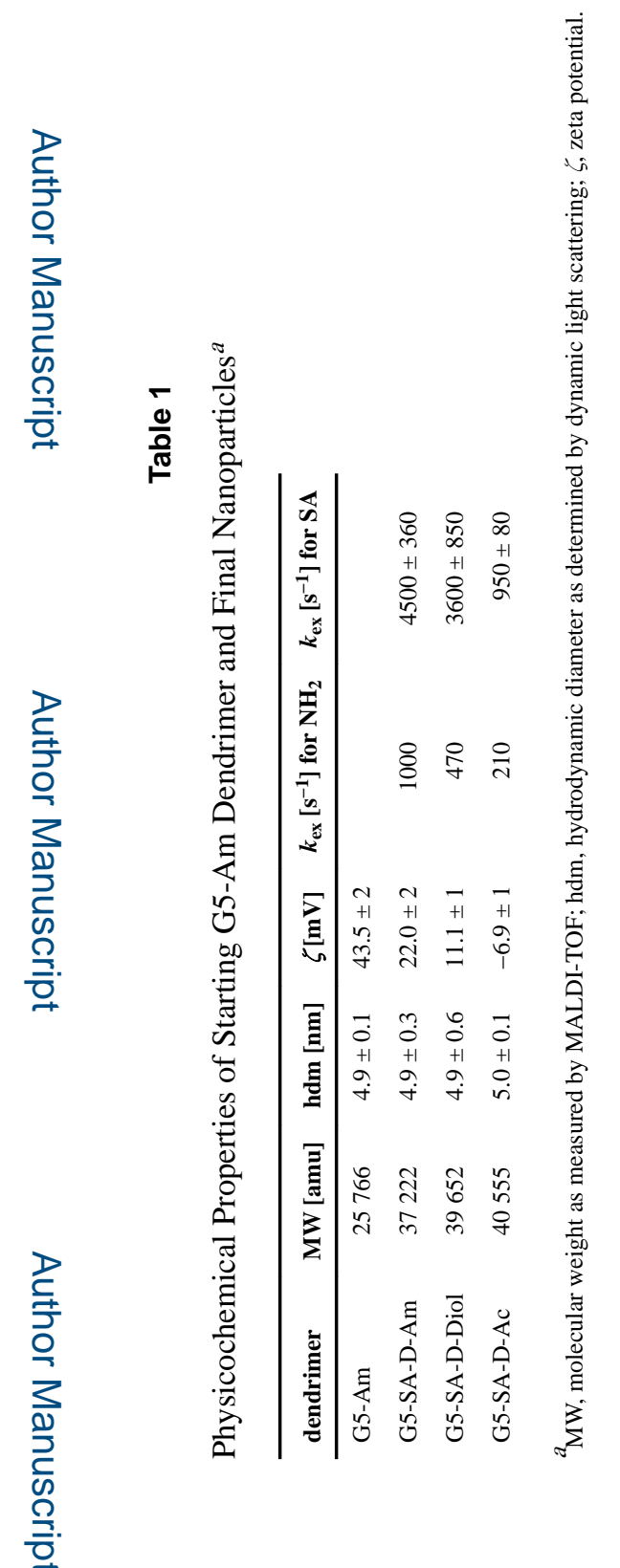

Nano Lett. Author manuscript; available in PMC 2017 April 13. 